\title{
ASSESSMENT OF THE LEVEL OF DEPRESSION AMONG SENIOR CITIZENS RESIDING IN SELECTED OLD AGE HOMES, AMRITSAR.
}

\author{
Mrs. Harjit Kaur* I Dr. Manjit Kaur Salwan**
}

*Ph.D. Scholar, Himalayan University, Itanagar, Arunachal Pradesh, India.

**Assistant Professor, NRI College of Nursing, Amritsar, Punjab, India.

DOI: http://doi.org/10.47211/trr.2020.v06i01.003

Received $10^{\text {th }}$ May 2020, Accepted $25^{\text {nd }}$ May 2020, Available online $25^{\text {th }}$ June 2020.

\section{ABSTRACT}

Depression is a serious global mental problem that affects people of all ages in the countries throughout the world that can be severe and sometimes fatal. Worldwide 300 million people are suffering from depression until 2025 it is estimated that there will be 400 million cases of depression. A descriptive study to assess the level of depression among senior citizen residing in selected old age homes, Amritsar". The descriptive survey research design was adopted for the present study. The self-structured questionnaire was used to collect the data. The study was conducted in the city of Amritsar from 60 samples. The collected data was analyzed and interpreted based on descriptive and inferential statistics. The results of the study showed that there was significant level of depression among geriatrics. Majority of the geriatrics $\{(29) 48.33 \%\}$ has mild depression, less majority $\{(15) 25 \%\}$ had moderate depression and least majority $\{(3) 5 \%\}$ has severe depression. Among the elderly \{(13)21.66\% are normal. There was a significant association of depression found among old age with their gender 8.86 at the significant level of 0.05, with their source of income 14.256 at the significance level of 0.05 and with their reason for staying 20.28 at the significance level of 0.01 and 0.05 ; However, no association was found when compared to age (9.778), marital status (2.51), duration of stay (11.72). In the biophysical profile there was no association found when compared to blood pressure (0.5963) and presence of disease (4.003).

Key Words: Depression, Assess, Aging, Old age home.

\section{About Authors}

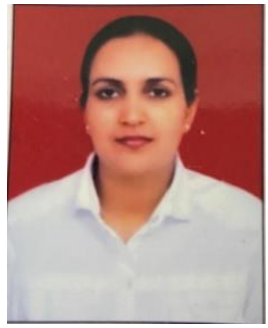

Author Mrs. Harjit Kaur is a PhD Scholar at Himalayan University at Itanagar in the Indian state of Arunachal Pradesh. She has attended various national seminars and workshops.

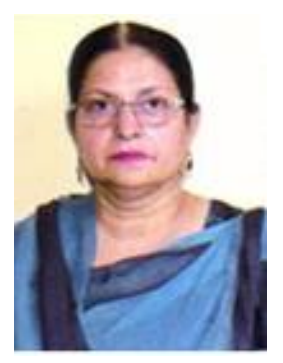

Author Dr. Manjit Kaur Salwan is the Principal of Guru Teg Bahadur College of Nursing, Amritsar in Punjab. She has presented paper at various conferences and seminars. 


\section{INTRODUCTION}

Change is the law of nature. Sun rises in the morning \& sets in the evening. Similarly aging is a natural process of human life. As every high tide is followed by low tide similarly every person has to face the grey shade of life. Old age is an incurable disease which is considered as an inevitable biological phenomenon. Every human being passes through different phases of life and reaches senior citizen at some point of time. This stage demands extra care and affection as the process of aging is said to be constant with bodily function and efficiency gradually declining. In old times the elderly people were treated with special respect \& regard because they were known for their wisdom \& experience. They were well versed with the ground realities and techniques of how to tackle problems. But now-a-days this enriched chunk of our society is treated as a junk or unproductive organ because no one is interested in them. They are considered out-dated, old fashioned and obsolete assets of modern society. In the modern nuclear family there is erosion in the status of the elderly persons. Placing the elders in old age homes is not uncommon; at times for valid reasons and sometimes forcefully. Old age, thus has become a matter of concern both in developed and developing nations.

Aging impacts memory, cognition, behavior, intelligence and personality and may lead to mental illness among elderly. Disease condition such as depression can cause depreciation in the mental capacity or performance of elderly person. Aging research has demonstrated a positive correlation of someone depression or the occurrence of depression is a prominent condition amongst the older people, with a significant impact on the wellbeing and quality of life. Many studies have demonstrated that the prevalence of depressive symptoms increases with age (kennedy, 1996)

According to WHO : Mental health is a state of wellbeing in which the individual realizes his or her own potentials, abilities and can cope with the normal stressors of his or her own life, can work productively and fruitfully and is able to make a contribution to his or her community.

\section{Need of Study}

The elderly are prized resources. We need to create a great awareness to safeguard the health and dignity of vulnerable section of society and help them live the rest of their lives with dignity. Elderly are the most rapidly growing segment of population.

Elderly person's sense of self and security may be threatened when it becomes necessary to adapt to various personal changes. Changes in physical status, loss of significant others, Hospitalization or movement to long term care facility have profound effect on the elderly persons sense of independence. Many factors contribute to the lineation of the elders. Migration of young couples from rural area to cities in search of better employment opportunities found for themselves. Elderly who have been in the control of household for a long time are unwilling to give off their responsibilities to their children.

\section{Statement of Problem:}

To assess the level of depression among the senior citizen residing in the old age homes of Amritsar.

\section{Objectives of study}

1. To assess the level of depression among geriatrics (age $>60 \mathrm{yrs}$ ) residing in selected old age home in Amritsar

2. To find out the association of depression with their selected demographic variables in old age home.

\section{RESEARCH METHODOLOGY}

Research Approach: Quantitative approach.

Research Design: Non- experimental

Research Setting: Old age homes Amritsar.

Target population: Elderly people above 60 years in age were included in the study residing in the selected old age home of Amritsar.

Sample and sampling technique: Sample in this study was elderly people above 60 years in age and Purposive sampling technique was used.

\section{Selection and development of tools:}

The following methods were used for the development of tool.

- $\quad$ Review of relevant literature (Textbooks, Journals, Periodicals \& Websites).

- Discussion with subject experts (Doctors, Nursing faculty, Statistician, Guide and personal experience of researcher). All these sources helped researcher to prepare the tool.

\section{Description of Tool:}

The tool consists of: 
PART 1-

- DEMOGRAPHIC VARIABLE: It is designed to provide background information regarding age, gender, marital status, source of income, reason for staying in old age home and duration of stay in the old age home.

PART -2

Deals with self-instructed geriatric scale. It consist of 25 questions to assess the level of depression in the sample.

$>$ SCORE :

- For Questions 1-18 yes $=1$, no $=0$

- For Questions $19-25$, yes $=0$, no $=1$

\section{Major findings of the study are:}

1. The findings of the study revealed that majority of the geriatrics $\{(29) 48.33 \%\}$ has mild depression, less majority $\{(15) 25 \%\}$ had moderate depression and least majority $\{(3) 5 \%\}$ has severe depression. Among the elderly $\{(13) 21.66 \%$ are normal.

2. The association of depression found among geriatric with their gender 8.86 at the significant level of 0.05 , with their source of income 14.256 at the significance level of 0.05 and with their reason for staying 20.28 at the significance level of 0.01 and 0.05 . However no association was found when compared to age (9.778), marital status (2.51), duration of stay (11.72) as the calculated value is less than the tabulated value. In the biophysical profile there was no association found when compared to blood pressure (0.5963) and presence of disease (4.003).

3. The results indicate that higher percentage of subjects $(71.66 \%)$ belongs to the age group above 70 yrs. In gender, the majority of the geriatric 55\% are female. In marital status, most of the geriatric 73.33\% are married. Majority of geriatric (43.3\%) have pension as their source of income. The reason for staying in old age home among most of the geriatric (46.66\%) is left by family. Majority of the geriatrics (41.6\%) are living in the old age from $1-2$ years.

4. Most of the geriatrics (90\%) has their blood pressure in the range $110 / 75 \mathrm{mmhg}-130 / 80 \mathrm{mmhg}$. Majority of geriatric (63.33\%) have systematic diseases.

5. Mean depression scores among geriatrics found to be 10.28 and standard deviation was 4.397 .

6. The study revealed that there was significant level of depression among geriatrics, $48.33 \%$ of the geriatrics had mild depression, less majority $25 \%$ had moderate depression and least majority $5 \%$ had severe depression, $21.66 \%$ of the elderly were normal and significant association between gender, source of income, reason for staying in old age home and depression.

\section{CONCLUSION:}

This chapter deals with the conclusion drawn based on the findings of the study. The conclusion drawn was:

The study revealed that there was significant level of depression among geriatrics, $48.33 \%$ of the geriatrics had mild depression, less majority $25 \%$ had moderate depression and least majority $5 \%$ had severe depression, $21.66 \%$ of the elderly were normal and significant association between gender, source of income, reason for staying in old age home and depression.

\section{RECOMMENDATIONS}

Based on the findings of study, the following recommendations are stated

$>\quad$ A similar study may be undertaken with a larger sample to generalize the findings,

$>$ Replication of study may be undertaken among psychiatric patients to enhance their mental wellbeing.

$>\quad$ An experimental study can be conducted to teach the coping strategies to cope up with depression. 


\section{ARTICLES}

\section{REFERENCES}

1. Benjamin James Sadock, Virginia Alcott Sadock (2002), Synopsis of Psychiatry, Ninth Edition. Philadelphia, Lippincott. Williams and Wilkins Publication. Page no.1321.

2. Polit Denise F, Beradethe P. Hungler. Essentials of Nursing Research. $5^{\text {th }}$ Edition. J. B. Lippincott Co; 2001. 24-26

3. Paul McGhee. Health, Healing and the Amuse System: Humor as Survival Training. Montclair, New Jersey, 1999., 20-23

4. R Sreevani. A text book of mental health and Psychiatric Nursing $2^{\text {nd }}$ edition 2007.

5. Julia B. George, Nursing Theories, the base for Professional Nursing Practice 6th edition page 186-187

6. WHO Health Forum 2004.

7. Rochell AM. Detection of depression in the cognitively intact older adult protocol, Journal of Gerentological Nsg. Jan 2001.

8. Tiwari SC Geriatric Psychiatric Morbidity in rural northern India; implication for the future. Int. psycho geriatrics 2000;12;5-48

9. Govt. of India. Report of Health Survey and Development Committee (Bhore Committee), vol. III, Appendix. New Delhi: Govt. of India, 1946: 73.

10. Satchner D. Mental Health- A report of the Surgeon General. 2000; 31: 15-23.

11. Kanade M., A Report of geriatric problems in rural northern India 2007 35-48.

12. Geerlings WS. Duration and Severity of depression predict mortality in order adult in the community, Psychological medicine 2002.

13. Blazer GD. Depressing symptoms of cognitive decline. British Journal of Psychiatric 2002.

14. Karen devereaux melilio. Susan crocker houd. Mental health geropsychiatric mental health nursing. $1^{\text {st }}$ edition: jones and barlet publisher 2005.

15. Ebersole P. caring for psychiatric client. New York: springer. 1989

16. Sharma SP. Aging in India. Inter India publications New Delhi. 2001 Park K. Text book of preventive and social medicine. $17^{\text {th }}$ edition. Banarsidas bhanot publisher.1991 